\title{
Porous Cotton-derived Carbon: Synthesis, Microstructure and Supercapacitive Performance
}

\author{
HAO Yan-Xia ${ }^{1,2}$, QIAN Meng ${ }^{1,2}$, XU Ji-Jian ${ }^{1}$, BI Hui ${ }^{1}$, HUANG Fu-Qiang ${ }^{1,3}$
}

(1. State Key Laboratory of High Performance Ceramics and Superfine Microstructure, CAS Key Laboratory of Materials for Energy Conversion, Shanghai Institute of Ceramics, Chinese Academy of Sciences, Shanghai 200050, China; 2. University of Chinese Academy of Sciences, Beijing 100049, China; 3. Beijing National Laboratory for Molecular Sciences and State Key Laboratory of Rare Earth Materials Chemistry and Applications, College of Chemistry and Molecular Engineering, Peking University, Beijing 100871, China)

\begin{abstract}
Biomass materials were widely used to synthesize porous carbon for energy storages considering the simple preparation method and wide availability of raw materials. Herein, we prepared nitrogen doped porous carbon from natural cotton via a simple one-step eco-friendly method. The cotton-derived carbon material delivers a maximum specific surface area of $480 \mathrm{~m}^{2} / \mathrm{g}$ and a high nitrogen content of $6.84 \%$ at the carbonization temperature of $750^{\circ} \mathrm{C}$. The obtained material shows excellent performance when used as supercapacitor electrode materials, which exhibits a maximal specific capacitance of $252 \mathrm{~F} / \mathrm{g}$ at $1 \mathrm{~A} / \mathrm{g}$ in $1 \mathrm{~mol} / \mathrm{L} \mathrm{H}_{2} \mathrm{SO}_{4}$ electrolyte and retains $94 \%$ of the capacitance after 10,000 cycles at $15 \mathrm{~A} / \mathrm{g}$. The good performance of the low-cost carbon electrode made from cotton provides a potential application for electrochemical capacitors.
\end{abstract}

Key words: cotton; porous carbon; supercapacitor

Supercapacitors show promising application on power-based applications such as hybrid electrical vehicle and high-power electronic devices due to high power density, long cycle life and safe operation ${ }^{[1-2]}$. Supercapacitors can be classified as electric double layer capacitor (EDLC) and Faraday capacitor according to the way charges are stored. Electric double layer capacitance comes from absorption and desorption of charges on the interface of electrode and electrolyte, while Faraday capacitance results from the reversible redox reactions in electrode materials ${ }^{[3-4]}$. The current electrode materials for supercapacitors are mainly polymer (polypyrrole, melamine $)^{[4-5]}$, transition metal oxide $\left(\mathrm{RuO}_{2}, \mathrm{MnO}_{2}\right)^{[6-7]}$ and carbon materials ${ }^{[8-10]}$. Considering about the low electrical conductivity and poor cycle stability of polymer and transition metal oxide which are limited in commercial application, carbon materials especially activated carbon are considered as the most potential electrode materials in view of their good electrical conductivity, low cost and safe operation.

Biomass-derived activated carbon materials are the most common used electrode materials due to their abundant sources, low cost and adjustable structure. To date, tremendous studies have been made on the biomass-derived carbon materials, such as pomelo peel ${ }^{[11]}$, cotton stalk ${ }^{[12]}$ catkin $^{[13]}$, cornstalk ${ }^{[14]}$ and bamboo ${ }^{[15]}$. Raw cotton as a common cheap natural material is widely distributed and contains more than $90 \%$ cellulose, endowing it a promising raw material for fabrication of carbon based materials by direct carbonization or activation process ${ }^{[16]}$. Generally, the activation process can greatly enhance performance for supercapacitors owing to increased specific surface area and doping of heteroatoms in the materials. However, the activation process for biomass-derived active carbon materials, including physical activation $\left(\mathrm{CO}_{2}, \mathrm{H}_{2} \mathrm{O}\right)^{[17-18]}$ and chemical activation $\left(\mathrm{H}_{3} \mathrm{PO}_{4}, \mathrm{KOH}\right.$, $\mathrm{NaOH})^{[19-20]}$ requires either high reaction temperature or complex steps which increase the cost for massive production. Therefore, it is necessary to develop facile methods for low-cost preparation of biomass-derived carbon materials.

Herein, we have reported a cotton-derived carbon (CDC) material through a simple one-step method. $\mathrm{LiCl} / \mathrm{KCl}$ and $\mathrm{LiNO}_{3}$ were used as activating agent and nitrogen

Received date: 2017-04-10; Modified date: 2017-05-16

Foundation item: National Key Research and Development Program (2016YFB0901600); National Natural Science Foundation of China (61376056); Science and Technology Commission of Shanghai (14520722000, 16JC1401700); Shanghai Science and Technology Development Funds (16QA1404200); Key Research Program of Chinese Academy of Sciences (KGZDEW-T06); China Youth Innovation Promotion Association, Chinese Academy of Sciences

Biography: HAO Yan-Xia(1990-), female, candidate of master degree. E-mail: haoyanxia@hlmc,cn

Corresponding author: HUANG Fu-Qiang, professor. E-mail: huangfq@mail.sic.ac.cn 
source, respectively.

\section{Experimental}

\subsection{Synthesis of cotton-derived carbon materials}

Medical cotton (Yinjing Medical Supplies Co., Ltd., Shanghai, China) was used as received without any other purification process. $\mathrm{LiCl}$ and $\mathrm{KCl}$ were purchased from Aladdin Reagent Co., Ltd., Shanghai, China. $\mathrm{LiNO}_{3}$ was purchased from Sigma Reagent Co., Ltd., Shanghai, China. All chemicals used were in analytical grade.

The cotton was firstly put into an oven to dry for $24 \mathrm{~h}$ at $200^{\circ} \mathrm{C}$ before next-step carbonization process. Then $1 \mathrm{~g}$ of cotton was mixed with $\mathrm{LiNO}_{3}$ and $\mathrm{LiCl} / \mathrm{KCl}$ on the weight ratio of cotton: $\mathrm{LiNO}_{3}:(\mathrm{LiCl} / \mathrm{KCl})=1: 1: 10$. The mixture was ground into powder with vigorously grinding. Heat treatment was conducted in double crucibles. In a typical process, the homogeneous mixture was put into a ceramic crucible covered by a ceramic lid. Then the crucible was put into a bigger crucible with graphite powder filling in the space between two crucibles for sufficient separation from air, followed by carbonization in muffle furnace. The carbonization was carried out at the temperature of 550,650 and $750^{\circ} \mathrm{C}$ for $2 \mathrm{~h}$ at a heating rate of $5{ }^{\circ} \mathrm{C} / \mathrm{min}$. After cooled to room temperature, the obtained samples were thoroughly washed with hot water to dissolve the inorganic salts. Finally, the samples were dried in a vacuum oven at $60^{\circ} \mathrm{C}$ for $24 \mathrm{~h}$ and marked as CDC- $x(x=550,650,750)$, where $x$ is the corresponding carbonization temperature. In comparison, we also carried out the experiment without any inorganic salts at $750^{\circ} \mathrm{C}$. The sample was marked as PC.

\subsection{Characterization}

Field emission scanning electron microscope (FESEM, Magellan 400, FEI Company) and transmission electron microscope (TEM, JEOL 2011 at $200 \mathrm{kV}$ ) were used to examine the morphologies and microstructures of the samples. The specific surface area (SSA) and pore structure results were based on $\mathrm{N}_{2}$ adsorption/desorption measurement (Micromeritics Tristar 3000). The SSA was calculated by Brunauer-Emmett-Teller (BET) method, while the pore structure curves were obtained from the adsorption branch of the isotherms by non-liner density functional theory (NLDFT) model. X-ray photoelectron spectroscopy (XPS, VGScientific ESCALAB Mark IIspectrometer) was used to determine the element composition. Raman spectra (Thermal Dispersive Spectrometer at $10 \mathrm{MW}$ laser) were collected with an excitation wavelength of $532 \mathrm{~nm}$.

\subsection{Electrochemical measurements}

The electrochemical measurements were evaluated on an electrochemical workstation (CHI 760E, Shanghai, China) in $1 \mathrm{~mol} / \mathrm{L} \mathrm{H}_{2} \mathrm{SO}_{4}$ aqueous solution. The working electrode was prepared as follows: $10 \mathrm{mg}$ of the obtained samples were dispersed in $2 \mathrm{~mL}$ PVDF (5 mg/mL in $\mathrm{NMP}$ ) to form a slurry, then $200 \mu \mathrm{L}$ of the slurry was dropped onto the 3D graphene foam electrode and dried subsequently in an oven at $120^{\circ} \mathrm{C}$ for $12 \mathrm{~h}$. For the threeelectrode system, Ag/AgCl electrode was served as reference electrode, while $\mathrm{Pt}$ wire was used as a counter electrode. For two-electrode cell tests, the two similar working electrodes made by the method talked above were symmetrically put in the $1 \mathrm{~mol} / \mathrm{L} \mathrm{H}_{2} \mathrm{SO}_{4}$ electrolyte.

Cyclic voltammetry (CV), galvanostatic chargingdischarging (GCD) were measured with the voltage within -0.2-0.8 $\mathrm{V}$ and $0-1.2 \mathrm{~V}$ for three-electrode system and two-electrode cell system, respectively. Electrochemical impedance spectra (EIS) were conducted at a frequency from $10 \mathrm{mHz}$ to $100 \mathrm{kHz}$.

The gravimetric specific capacitance $\left(C_{\mathrm{g}}\right)$ and energy density $(E)$ were calculated using the following formulas:

$$
\begin{gathered}
C_{\mathrm{g}}=I \times \mathrm{d} t / m \times \mathrm{d} V \\
E=1 / 2 \times C_{\mathrm{g}} \times V^{2} / 3.6
\end{gathered}
$$

Where $C_{\mathrm{g}}$ is the specific capacitance of the samples $(\mathrm{F} / \mathrm{g})$, $I$ is the discharge current (A), $\mathrm{d} t$ is the discharge time (s), $\mathrm{d} V$ and $V$ is the potential window (V), $m$ is the total weight of the electrode material (g) and $E$ is the energy density of the two-electrode system $((\mathrm{W} \cdot \mathrm{h}) / \mathrm{Kg})$.

\section{Results and discussion}

Medical cotton obtained by simply bleaching and degreasing processes of cotton is mainly composed of cellulose and can be used as biomass-derived activated carbon materials. In this work, we use inorganic molten salts to activate medical cotton in the double crucibles. Specifically, the inorganic salts and cotton used are put into an inner crucible, with graphite filling between the two crucibles for separation of air layer and samples. $\mathrm{LiCl} / \mathrm{KCl}$ is used as an activating agent and $\mathrm{LiNO}_{3}$ is used as nitrogen source. The specific carbonization steps were carried out as illustrated in Fig. 1(a).

SEM images of PC and CDC-750 are shown in Fig. 1(b) and Fig. 1(c). As can be seen, the PC presents a fibrous structure, the same as the raw cotton material (Fig. S1). Much different with PC, CDC-750 exhibits small block structure, which is similar with CDC-550 and CDC-650 (Fig. S2(a)-S2(b)). The difference between PC and CDC samples implies that the addition of inorganic salt can destroy the structure of the raw materials. Fig. 2 gives the TEM and high-resolution TEM images of CDC-750. We can see that the sample presents porous structure in the surface. In addition, the continuous gra- 
phite stripe demonstrates that the sample is graphited from the high-resolution TEM.

Figure 3 shows the $\mathrm{N}_{2}$ adsorption-desorption isotherms and pore size distribution spectra of PC and CDC samples. The specific surface area is analysed according to BET method and the pore size distribution is obtained by non-liner density functional theory (NLDFT) model. Clearly, the isotherm of PC shows the typical curve of type I, an indication of micropore in PC, while the isotherms of CDC are typical IV curves implying the existence of both micropore and mesopore based on International Union of Pure and Applied Chemistry ${ }^{[21]}$. The specific surface area, total pore volume and micropore volume of PC and CDC are listed in Table 1 . As can be seen, the PC has only micropore while CDC possess both micropore and mesopore implying that inorganic salts can produce mesopore. Furthermore, with the increase of carbonized temperature, the specific surface area and micropore volume of CDC increase, while the mesopore volume decreased, indicating that high temperature will destroy the mesopore structure.

Figure 4(a) shows the Raman spectra of CDC and PC. The characteristic peak located at $1350 \mathrm{~cm}^{-1}$ (D band) represents the degree of disorder, while the peak at $1580 \mathrm{~cm}^{-1}$ (G band) implies the degree of graphitization. CDC show decreased $G$ peak compared with PC, indicating that the addition of inorganic salt can etch carbon atoms to increase the defect which is consistent with SEM results. More importantly, with increasing of temperature, the CDC show decline of $G$ peak, implying the decreased graphitization. It's known that high temperature is beneficial for graphitization of carbon materials ${ }^{[22]}$, while the circumstance is opposite in our work. That may result from the higher reactivity of inorganic salts with carbon atoms at high temperature which introduces stronger etch of carbon atoms.

In order to explore the element composition of the samples, X-ray photoelectron spectroscopy (XPS) is performed. Figure 4(b) shows the XPS of all the samples.

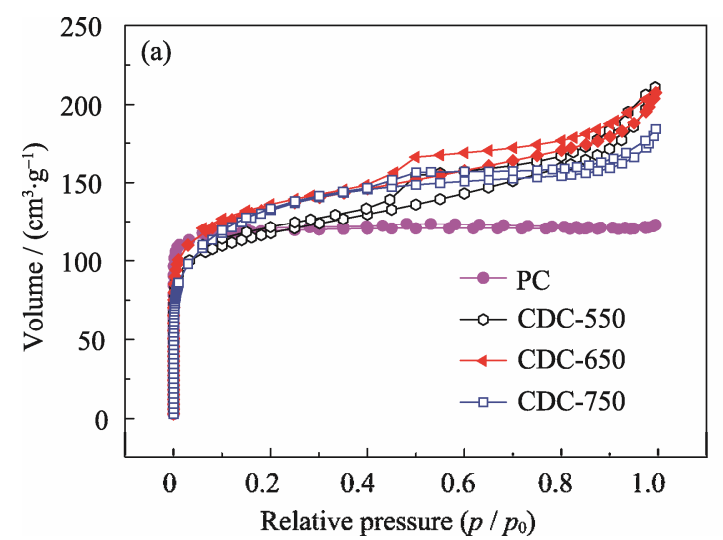

PC exhibits only $\mathrm{C}$ and $\mathrm{O}$ elements peaks, while CDC show additional $\mathrm{N}$ element, implying that $\mathrm{LiNO}_{3}$ can be used as a nitrogen source, as discussed in our former work $^{[23]}$. Furthermore, the nitrogen content can reach as high as $6.84 \%$ (Table 1). High resolution XPS spectrum of C1s of CDC-750 was given in Fig. 4(c), C1s peak can be divided into four different peaks, which represent $\mathrm{C}=\mathrm{C}$ at $284.6 \mathrm{eV}, \mathrm{C}=\mathrm{N}$ at $285.4 \mathrm{eV}, \mathrm{C}-\mathrm{N}$ at $286.5 \mathrm{eV}$ and $\mathrm{O}-\mathrm{C}=\mathrm{O}$ at $289.4 \mathrm{eV}$. Meanwhile, The N1s peak of CDC-550, CDC-650 and CDC-750 were also conducted in Fig. 4(d) and Fig. S3. Clearly, N1s can be divided with three relative peaks: pyridine $\mathrm{N}-6$ at $398 \mathrm{eV}$, pyrrole N-5 at $400 \mathrm{eV}$ and graphitization $\mathrm{N}-\mathrm{Q}$ at $401 \mathrm{eV}$, respectively ${ }^{[24-25]}$. The results reveal that nitrogen is doped into carbon atoms owing to the reaction between $\mathrm{LiNO}_{3}$ and

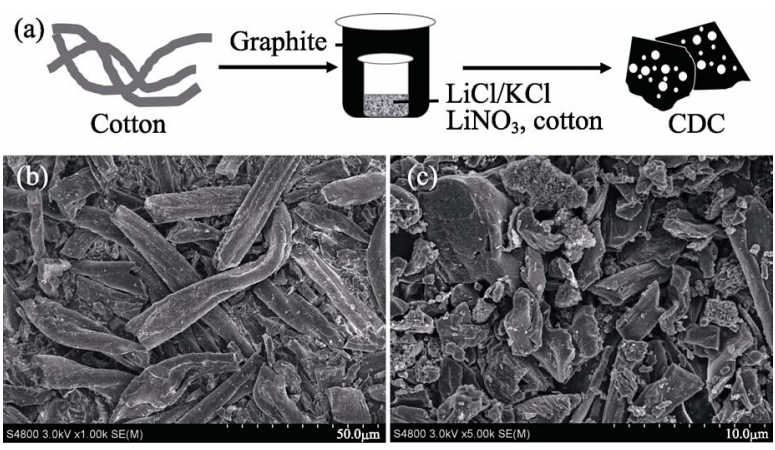

Fig. 1 (a) Schematic synthesis of cotton-derived carbon samples and SEM images of PC (b) and CDC-750 (c)
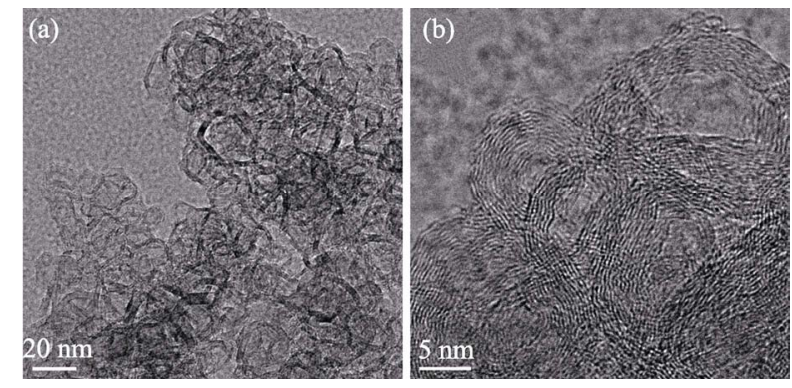

Fig. 2 TEM images of CDC-750

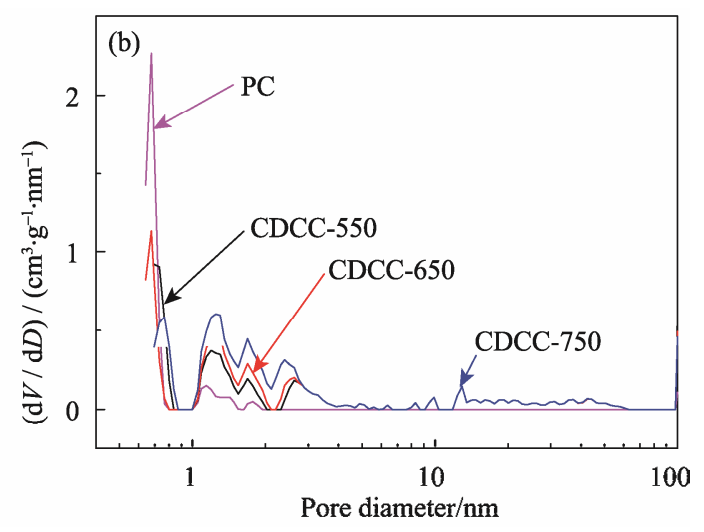

Fig. $3 \mathrm{~N}_{2}$ absorption-desorption isotherm (a) and pore size distribution (b) of PC and CDC samples 
Table 1 Porous properties and elements composition of the obtained samples

\begin{tabular}{cccccccc}
\hline Sample & $S_{\mathrm{BET}} /\left(\mathrm{m}^{2} \cdot \mathrm{g}^{-1}\right)$ & $V_{\mathrm{t}}^{\mathrm{I}} /\left(\mathrm{m}^{3} \cdot \mathrm{g}^{-1}\right)$ & $V_{m}^{\mathrm{II}} /\left(\mathrm{m}^{3} \cdot \mathrm{g}^{-1}\right)$ & $\mathrm{N} / \%$ & $(\mathrm{~N}-5) / \%$ & $(\mathrm{~N}-6) / \%$ & $(\mathrm{~N}-\mathrm{Q}) / \%$ \\
\hline PC & 397 & 0.1312 & 0.1312 & $/$ & $/$ & $/$ & $/$ \\
CDC-550 & 403 & 0.2682 & 0.1127 & 6.15 & 28.65 & 25.47 & 45.88 \\
CDC-650 & 460 & 0.2619 & 0.1403 & 6.52 & 32.53 & 25.31 & 42.16 \\
CDC-750 & 480 & 0.2458 & 0.1576 & 6.84 & 47.14 & 20.98 & 31.88 \\
\hline
\end{tabular}

I The total pore volume with pore diameter less than $354 \mathrm{~nm}$ at $p / p_{0}=0.994$

II DFT microspore volume
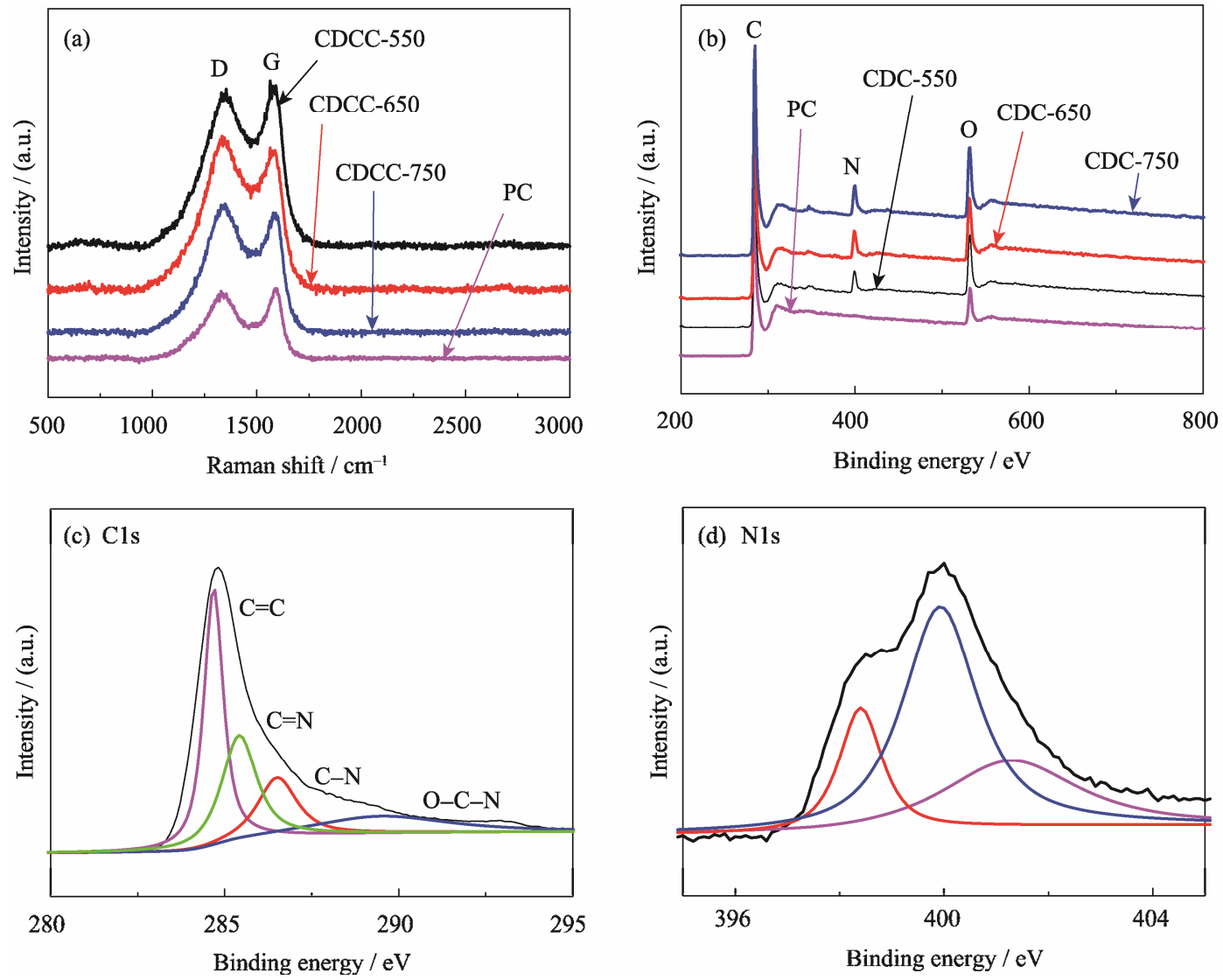

Fig. 4 Raman spectra (a) and XPS spectra (b) of all the samples, C1s peak of CDC-750 (c) and N1s peak of CDC-750 (d)

carbon atoms. Although the nitrogen contents of the three samples are basically the same, the pyridine nitrogen and pyrrole nitrogen quantum is increasing (Table 1), in direct proportion to temperature.

When used as supercapacitor electrode materials, pyridine nitrogen and pyrrole nitrogen can introduce Faradic capacitor through the reversible reaction on electrode material surface which is beneficial to the supercapacitor performance $^{[26]}$.

With high specific surface area, micropore volume and nitrogen content, CDC can be a good option for supercapacitor electrode materials.

Figure 5(a) shows the GCD curves at a current density of $1 \mathrm{~A} / \mathrm{g}$ in the potential range between -0.2 and $0.8 \mathrm{~V}$. the GCD curves exhibit good symmetry, implying good charge and discharge properties and electrochemical reversibility. The capacitance is 75, 140, 235 and 252 F/g for
PC, CDC-550, CDC-650 and CDC-750, respectively. The relative high capacitance of CDC-750 root in the high specific, micropore volume and electrochemical reactive nitrogen content as discussed above, higher than the previously reported biomass-derived carbon materials $^{[27-28]}$.

Figure 5(b) shows the CV curves of CDC-750 at different scan rates. Clearly, the CDC-750 curves present approximate rectangle shape, implying good electric double layer capacitors performance. Furthermore, even at a high scan speed of $100 \mathrm{mV} / \mathrm{s}$, the CDC-750 still keeps the nearly rectangle shape, demonstrating good capacitive performance ${ }^{[29-30]}$. GCD curves at different current densities in Fig. 5(c) show that CDC-750 can have $75 \%$ capacitance retention at $15 \mathrm{~A} / \mathrm{g}$ and possesses good rate performance. 

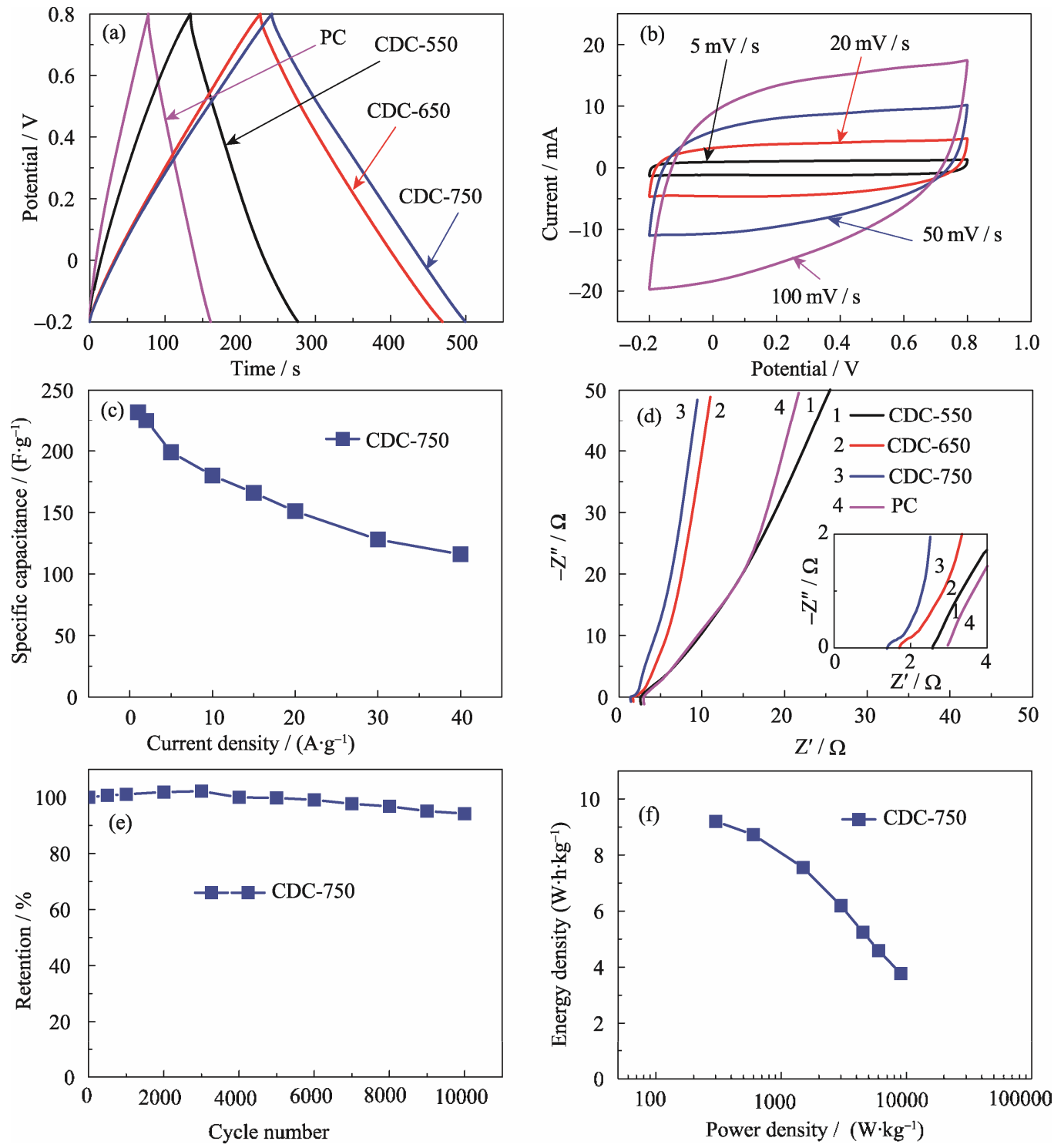

Fig. 5 (a) GCD curves of samples at a current density of $1 \mathrm{~A} / \mathrm{g}$, (b) CV curves of CDC-750 at different scan rates, (c) specific capacitance of CDC-750 at different current densities, (d) EIS spectra of the obtained samples, (e) cycle performance of

CDC-750 at a current density of $15 \mathrm{~A} / \mathrm{g}$, and (f) Ragone plot of symmetrical cell structure of CDC-750

Electrochemical impedance spectroscopy (EIS) of the CDC and PC samples are given in Fig. 5(d). As we can see, the CDC-750 sample has the lowest equivalent series resistance (ESR) in the high frequency area in the enlarged plot. Meanwhile, the CDC-750 sample presents approximate vertical lines in the low frequency, indicating ideal double-layer capacitance behaviour ${ }^{[1,28]}$. The continuous GCD curves was also carried out to explore the cycling performance of CDC-750 at a current density of $15 \mathrm{~A} / \mathrm{g}$ (Fig. 5(e)). Clearly, the sample even have 94\% capacity retention after 10000 cycles at $15 \mathrm{~A} / \mathrm{g}$, implying good cycling stability.

The symmetrical cell measurement for CDC-750 in $1 \mathrm{~mol} / \mathrm{L} \mathrm{H}_{2} \mathrm{SO}_{4}$ at a voltage window of $0-1.2 \mathrm{~V}$ was also conducted. The $\mathrm{CV}$ curves at different scan rates were given in Fig. S4 and the relevant Ragone plot was obtained at different current densities (Fig. 5(f)). CDC-750 can achieve an energy density of $9.2(\mathrm{~W} \cdot \mathrm{h}) / \mathrm{kg}$ at the power density of $0.3 \mathrm{~kW} / \mathrm{kg}$. The energy density of the cotton-derived porous carbon is higher than the previously reported materials, showing that CDC can be a good candidate for commercial supercapacitor application ${ }^{[31-33]}$.

\section{Conclusions}

In summary, we prepared cotton-derived porous carbon via a simple one-step method. The obtained CDC samples deliver a maximum SSA of $480 \mathrm{~m}^{2} / \mathrm{g}$ and a high nitrogen content of $6.84 \%$ at the carbonization temperature of $750^{\circ} \mathrm{C}$. When used as supercapacitor electrode materials, The CDC-750 can reach a specific capacitance of $252 \mathrm{~F} / \mathrm{g}$ at $1 \mathrm{~A} / \mathrm{g}$ in $1 \mathrm{~mol} / \mathrm{L} \mathrm{H}_{2} \mathrm{SO}_{4}$ electrolyte. Meanwhile, when the CDC-750 sample is assembled into a symmetrical cell, it 
can achieve an energy density of $9.2(\mathrm{~W} \cdot \mathrm{h}) / \mathrm{kg}$ at the power density of $0.3 \mathrm{~kW} / \mathrm{kg}$, showing the potential application in supercapacitor.

\section{References:}

[1] ZHU Y, MURALI S, STOLLER M D, et al. Carbon-based supercapacitors produced by activation of graphene. Science, 2011, 332(6037): 1537-1541.

[2] THOUNTHONG P, RAËL S, DAVAT B. Control strategy of fuel cell/supercapacitors hybrid power sources for electric vehicle. J. Power Sources, 2006, 158(1): 806-814.

[3] ZHANG L L, ZHAO X S. Carbon-based materials as supercapacitor electrodes. Chem. Soc. Rev., 2009, 38(9): 2520-2531.

[4] FAN L Z, MAIER J. High-performance polypyrrole electrode materials for redox supercapacitors. Electrochem. Commun., 2006, 8(6): 937-940.

[5] LI M, XUE J. Integrated synthesis of nitrogen-doped mesoporous carbon from melamine resins with superior performance in supercapacitors. J. Phys. Chem. C, 2014, 118(5): 2507-2517.

[6] BI R R, WU X L, CAO F F, et al. Highly dispersed $\mathrm{RuO}_{2}$ nanoparticles on carbon nanotubes: facile synthesis and enhanced supercapacitance performance. J. Phys. Chem. C, 2010, 114(6): 2448-2451.

[7] KIM H, POPOV B N. Synthesis and characterization of MnO2-based mixed oxides as supercapacitors. J. Electrochem. Soc., 2003, 150(3): D56-D62.

[8] PANDOLFO A G, HOLLENKAMP A F. Carbon properties and their role in supercapacitors. J. Power Sources, 2006, 157(1): 11-27.

[9] LIN T, CHEN I W, LIU F, et al. Nitrogen-doped mesoporous carbon of extraordinary capacitance for electrochemical energy storage. Science, 2015, 350(6267): 1508-1513.

[10] LIU C, YU Z, NEFF D, et al. Graphene-based supercapacitor with an ultrahigh energy density. Nano lett., 2010, 10(12): 4863-4868.

[11] LIANG Q, YE L, HUANG Z H, et al. A honeycomb-like porous carbon derived from pomelo peel for use in high-performance supercapacitors. Nanoscale, 2014, 6(22): 13831-13837.

[12] CHEN M, KANG X, WUMAIER T, et al. Preparation of activated carbon from cotton stalk and its application in supercapacitor. J. Solid State Electrochem., 2013, 17(4): 1005-1012.

[13] WANG K, ZHAO N, LEI S, et al. Promising biomass-based activated carbons derived from willow catkins for high performance supercapacitors. Electrochim. Acta, 2015, 166: 1-11.

[14] WANG L, MU G, TIAN C, et al. Porous graphitic carbon nanosheets derived from cornstalk biomass for advanced supercapacitors. ChemSusChem, 2013, 6(5): 880-889.

[15] YANG C S, JANG Y S, JEONG H K. Bamboo-based activated carbon for supercapacitor applications. Curr. Appl. Phys., 2014, 14(12): 1616-1620.

[16] WANG S, REN Z, LI J, et al. Cotton-based hollow carbon fibers with high specific surface area prepared by ammonia etching for supercapacitor application. RSC Adv., 2014, 4(59): 31300-31307.

[17] AHMADPOUR A, DO D D. The preparation of active carbons from coal by chemical and physical activation. Carbon, 1996, 34(4): 471-479.
[18] RODRIGUEZ-REINOSO F, MOLINA-SABIO M. Activated carbons from lignocellulosic materials by chemical and/or physical activation: an overview. Carbon, 1992, 30(7): 11111118.

[19] LILLO-RÓDENAS M A, CAZORLA-AMORÓS D, LINARESSOLANO A. Understanding chemical reactions between carbons and $\mathrm{NaOH}$ and $\mathrm{KOH}$ : an insight into the chemical activation mechanism. Carbon, 2003, 41(2): 267-275.

[20] FRACKOWIAK E, METENIER K, BERTAGNA V. Supercapacitor electrodes from multiwalled carbon nanotubes. Appl. Phys. Lett., 2000, 77: 2421-2423.

[21] XU J, DING W, ZHAO W, et al. In situ growth enabling ideal graphene encapsulation upon mesocrystalline $\mathrm{MTiO}_{3}(\mathrm{M}=\mathrm{Ni}$, Co, Fe) Nanorods for stable lithium storage. ACS Energy Lett., 2017, 2: 659-663.

[22] GAMBY J, TABERNA P L, SIMON P, et al. Studies and characterisations of various activated carbons used for carbon/ carbon supercapacitors. J. Power Sources, 2001, 101(1): 109116.

[23] HAO Y, XU F, QIAN M, et al. Low-cost and massive preparation of nitrogen-doped porous carbon for supercapacitor application. RSC Adv., 2017, 7(18): 10901-10905.

[24] ZHENG C, ZHOU X, CAO $\mathrm{H}$, et al. Synthesis of porous graphene/activated carbon composite with high packing density and large specific surface area for supercapacitor electrode material. J. Power Sources, 2014, 258: 290-296.

[25] XU J, DONG W, SONG C, et al. Black rutile (Sn, Ti) $\mathrm{O}_{2}$ initializing electrochemically reversible $\mathrm{Sn}$ nanodots embedded in amorphous lithiated titania matrix for efficient lithium storage. J. Mater. Chem. A, 2016, 4(40): 15698-15704.

[26] YOU B, WANG L, YAO L, et al. Three dimensional N-doped graphene-CNT networks for supercapacitor. Chem. Commun., 2013, 49(44): 5016-5018.

[27] LI L, ZHONG Q, KIM N D, et al. Nitrogen-doped carbonized cotton for highly flexible supercapacitors. Carbon, 2016, 105: 260-267.

[28] LU B, HU L, YIN H, et al. Preparation and application of capacitive carbon from bamboo shells by one step molten carbonates carbonization. Int. J. Hydrogen Energy, 2016, 41(41): 18713-18720.

[29] CHEN L F, ZHANG X D, LIANG H W, et al. Synthesis of nitrogen-doped porous carbon nanofibers as an efficient electrode material for supercapacitors. ACS nano, 2012, 6(8): 7092-7102.

[30] KIM T, JUNG G, YOO S, et al. Activated graphene-based carbons as supercapacitor electrodes with macro-and mesopores. ACS Nano, 2013, 7(8): 6899-6905.

[31] SUBRAMANIAN V, LUO C, STEPHAN A M, et al. Supercapacitors from activated carbon derived from banana fibers. J. Phys. Chem. C, 2007, 111(20): 7527-7531.

[32] KIM C, CHOI Y O, LEE W J, et al. Supercapacitor performances of activated carbon fiber webs prepared by electrospinning of PMDA-ODA poly (amic acid) solutions. Electrochim. Acta, 2004, 50(2): 883-887.

[33] KALPANA D, CHO S H, LEE S B, et al. Recycled waste paper-a new source of raw material for electric double-layer capacitors. J. Power Sources, 2009, 190(2): 587-591. 


\title{
棉花基多孔碳材料的合成、微结构及超电性能研究
}

\author{
郝燕霞 ${ }^{1,2}$, 钱 猛 ${ }^{1,2}$, 徐吉健 ${ }^{1}$, 毕 辉 ${ }^{1}$, 黄富强 ${ }^{1,3}$
}

(1. 中国科学院上海硅酸盐研究所, 高性能陶瓷和超微结构国家重点实验室, 中国科学院光电转换材料重点实验 室, 上海 200050；2. 中国科学院大学, 北京 100049; 3. 北京大学 化工与分子工程学院, 北京分子科学国家实验 室, 稀土材料化学及应用国家重点实验室, 北京 100871)

摘 要: 由于制备方法简单并且原料易得, 多孔碳合成广泛采用生物质材料, 并用于能源存储。以天然生物质棉花 作为碳源, 通过简单的一步法制备得到氮掺杂多孔碳材料。这种多孔碳材料在碳化温度为 $750^{\circ} \mathrm{C}$ 时具有 $480 \mathrm{~m}^{2} / \mathrm{g}$ 的 比表面积和 $6.84 \%$ 的高含氮量。当用作超级电容器电极材料时, 这种碳材料显示出了良好的电容性能。在 $1 \mathrm{~mol} / \mathrm{L}$ 硫酸电解液中, 电流密度为 $1 \mathrm{~mol} / \mathrm{L}$ 时, 比电容可以达到 $252 \mathrm{~F} / \mathrm{g}$, 并且在循环 10000 圈之后仍能保留 $94 \%$ 的原电容。 这种低成本的棉花基碳材料为超级电容器应用提供了可能。

关 键 词: 棉花; 多孔碳; 超级电容器

中图分类号: TQ174 文献标识码: A 
Supporting Information

\title{
Porous Cotton-derived Carbon: Synthesis, Microstructure and Supercapacitive Performance
}

\author{
HAO Yan-Xia ${ }^{1,2}$, QIAN Meng ${ }^{1,2}$, XU Ji-Jian ${ }^{1}$, BI Hui ${ }^{1}$, HUANG Fu-Qiang ${ }^{1,3}$
}

(1. State Key Laboratory of High Performance Ceramics and Superfine Microstructure, CAS Key Laboratory of Materials for Energy Conversion, Shanghai Institute of Ceramics, Chinese Academy of Sciences, Shanghai 200050, China; 2. University of Chinese Academy of Sciences, Beijing 100049, China; 3. Beijing National Laboratory for Molecular Sciences and State Key Laboratory of Rare Earth Materials Chemistry and Applications, College of Chemistry and Molecular Engineering, Peking University, Beijing 100871, China)

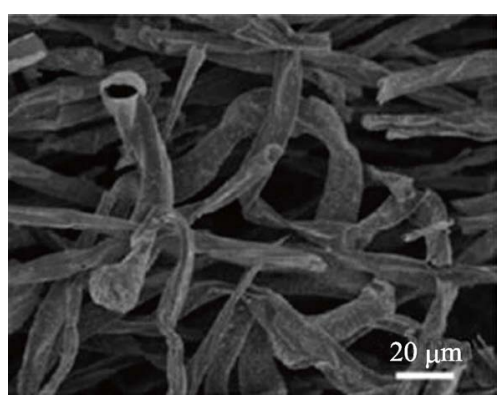

Fig. S1 SEM image of the raw cotton material
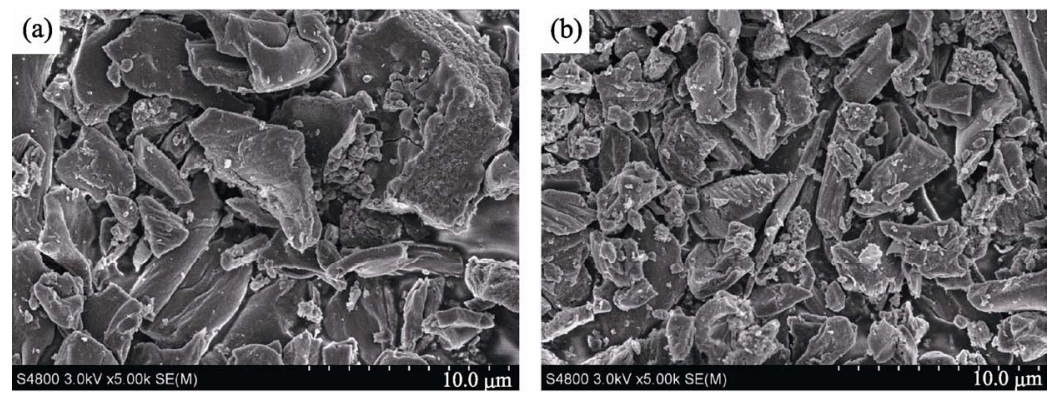

Fig. S2 SEM images of CDC-550 (a) and CDC-650 (b)
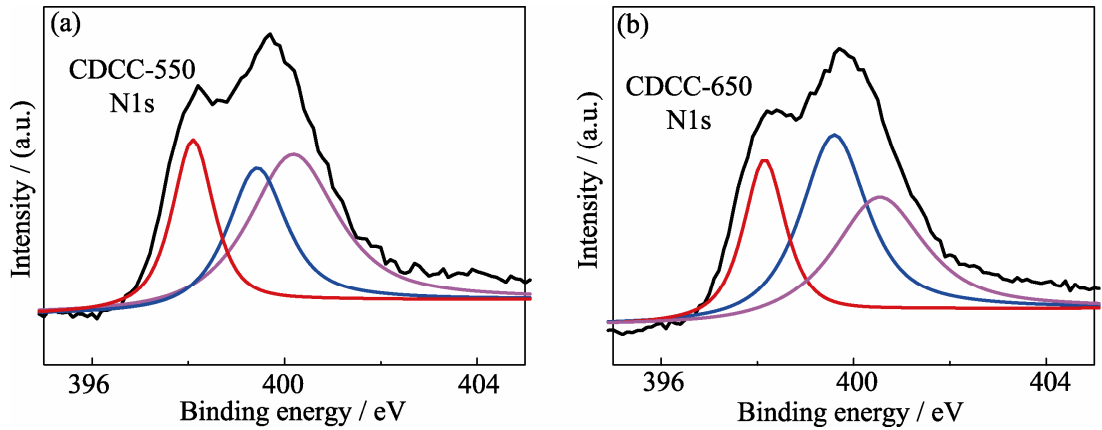

Fig. S3 N1s peak CDC-550 (a) and CDC-650 (b)

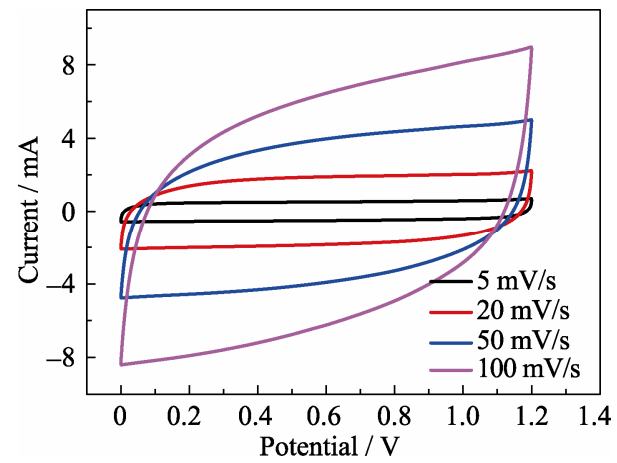

Fig. S4 CV curves of CDC-750 at different scan rates for symmetrical cell 